Bakhtiiarov, D. I., Lavrynenko, O. Y., Lishchynovska, N. O., \& Komarnytskyi, O. O. (2020). Methods of evaluation and forecasting of levels of electromagnetic radiation in urban environments. Actual Issues of Modern Science. Collection of Scientific Articles. European Scientific e-Journal, 6, 2, 40-54. Hlučín-Bobrovníky: "Anisiia Tomanek" OSVČ. (in Ukrainian)

Бахтіяров, А. І., Аавриненко, О. Ю., Аіщиновська, Н. О., Комарницький, О. О. (2020). Методи оцінювання та прогнозування рівнів електромагнітних випромінювань в урбанізованих середовищах. Actual Issues of Modern Science. Collection of Scientific Articles. European Scientific e-Journal, 6, 2, 40-54. HlučínBobrovníky: “Anisiia Tomanek” OSVČ.

DOI: $10.47451 /$ inn2020-12-001

The paper is published in Crossref, ICI Copernicus, BASE, Academic Resource Index ResearchBib, J-Gate, ISI International Scientific Indexing, Zenodo, OpenAIRE, BASE, LORY, ADL, Mendeley, eLibrary, and WebArchive databases.

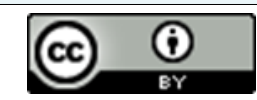

Denys I. Bakhtiiarov, Graduate Assistant, National Aviation University. Kyiv, Ukraine. ORCID: 0000-0003-3298-4641.

Oleksandr Y. Lavrynenko, Graduate Assistant, National Aviation University. Kyiv, Ukraine. Nataliia O. Lishchynovska, Graduate Assistant, National Aviation University. Kyiv, Ukraine. ORCID: 0000-0002-1913-8419.

Oleg O. Komarnytskyi, Graduate Assistant, Deputy Head of the Department of Strategic Planning, Department of Transport Infrastructure, Kiev State Administrative Administration. Kyiv, Ukraine.

ORCID: 0000-0003-4038-9906.

\title{
Methods of evaluation and forecasting of levels of electromagnetic radiation in urban environments
}

Abstract: This article is devoted to the decision of the actual scientific and applied problem which consists in the development of a method of definition of levels of the basic and secondary electromagnetic radiations in the urban environments at the expense of perfection of models of their distribution. The necessity in the increased efficiency of use of devices of monitoring of an electromagnetic situation on the basis of the analysis of features of distribution of electromagnetic radiations in the urban environment and lacks of the existing mathematical device for their description is proved. The nature of the interference and the distance in real operating conditions and the corresponding graphical and mathematical dependences were obtained, which formed the basis of the method of improving the models of electromagnetic radiation propagation. Scientific methods of synthesis of the detailed structural scheme of processes of detection and localization of uncontrolled and unlicensed devices of information transmission on radio channels, including development of the software for definition of a zone of electromagnetic accessibility indoors are substantiated. An original approach, algorithm of functioning and methods of synthesis of search means in the conditions of radio interference and detection of sources of electromagnetic radiation are developed.

Key words: secondary electromagnetic radiation; electromagnetic reach; radio wave propagation; Hut model; COST 231 MWM; monitoring of the electromagnetic environment, attenuation factor.

Аенис ІАшатович Бахтіяров, ЗАобувач, Національний авіаційний університет. Київ, Україна. ORCID: 0000-0003-3298-4641.

ОАександр Юрійович Аавриненко, 3Аобувач, Національний авіаційний університет. Київ, Україна.

Наталія ОАександрівна Аіщиновська, ЗАобувач, Національний авіаційний університет. Київ, Україна. ORCID: 0000-0002-1913-8419. 
ОАег ОАександрович Комарницький, 3Аобувач, Заступник начальника відАілу стратегічного планування, Аепартамент транспортної інфраструктури, Київська міська державна адміністрація. Київ, Україна. ORCID: 0000-0003-4038-9906.

\section{Методи оцінювання та прогнозування рівнів електромагнітних випромінювань в урбанізованих середовищах}

Анотаиія: Аана стаття присвячена рішенню актуальної науково-прикладної задачі, яка полягає в розробці методу визначення рівнів основних та побічних електромагнітних випромінювань в урбанізованих середовищах за рахунок удосконалення моделей їх розповсюдження. Обгрунтовано необхіАність в піАвищені ефективності використання пристроїв моніторингу електромагнітної обстановки на основі аналізу особливостей розповсюдження електромагнітних випромінювань в урбанізованому середовищі та недоліків існуючого математичного апарату Аля

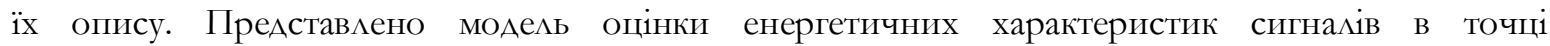
спостереження на основі експериментальних досліджень затухання електромагнітних випромінювань в залежності віА частоти, характеру перешкоди та віАстані в реальних умовах експлуатації та отримано віАповідні графічні й математичні залежності, що Аягли в основу методу удосконалення моделей розповсюдження електромагнітних випромінювань. Обгрунтовано наукові методи синтезу деталізованої структурної схеми процесів виявцення та цокалізації неконтрольованих та неліцензованих пристроїв передавання інформації по радіоканалах, що включають розробку програмного забезпечення Аля визначення зони електромагнітної Аоступності всередині приміщення. Розроблено оригінальний пілхіА, алгоритм функціонування та методи синтезу засобів пошуку в умовах радіоперешкоА та виявлення Ажерел електромагнітних випромінювань.

Кллочові слова: побічні електромагнітні випромінювання, зона електромагнітної Аоступності, розповсюдження радіохвиль, модель Хата, модель COST 231 MWM, моніторинг електромагнітної обстановки, коефіцієнт затухання.

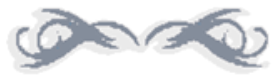

\section{Вступ}

Комплекси радіомоніторингу електромагнітної обстановки широко використовуються як інструмент Аля вирішення проблем у різних сферах - від управління використанням радіочастотних ресурсів до визначення областей енергетичного покриття при оцінці якості радіозв’язку. На додаток до конкретних завдань радіомоніторингу використання вищезазначених методів знаходить свої застосування Аля потреб електрозв'язку. Це, в свою чергу, призводить Ао необхіАності розрахунків зони «покриття», або зони ЕMА, та інтеграцію радіочастотних систем, найбільш доцільних 3 точки зору вимог ефективності використання радіотехнічних пристроїв моніторингу електромагнітної обстановки.

Прикладна частина, яка використовується Аля вирішення даного завдання, вкАючає перевірку аналітичних піАходів та розробку методів забезпечення моніторингу електромагнітних випромінювань, оцінку операційної ефективності Аля забезпечення електромагнітної Аоступності з урахуванням впливу урбанізованого середовища на характер розповсюдження електромагнітних випромінювань.

Проблема підвищення ефективності використання пристроїв моніторингу електромагнітних випромінювань стала актуальною внаслілок збільшення кількості 
міжнародних контактів та мібералізації ринку засобів ра^іозвязку, а також загроз з боку зловмисників, які збирають інформацію про промислові та економічні таємниці державних та комерційних установ. Поява на новому рівні проблеми захисту інформації та розрахунку периметрів контрольованих зон наочно продемонстрували певне наукове і особливо технічне відставання вітчизняних засобів радіомоніторингу, зАатних адекватно протистояти Ааними загрозам при проведенні контролю рівнів електромагнітних випромінювань, виявленні і мокалізації потенційно небезпечних джерел радіовипромінювання, виявленні електромагнітних випромінювань і наведень, зАатних призвести до витоку конфіленційної інформації.

Метою Ааного оригінального Аослідження є підвищення ефективності використання приладів радіомоніторингу в умовах складного характеру розповсюдження радіохвиль всередині приміщень. ВіАповіАно до цього було запропоновано метод розрахунків рівнів основних та побічних електромагнітних випромінювань Аля потреб радіомоніторингу, що зАатен враховувати втрати потужності радіосигналу на подолання різних типів перешкод всередині приміщень (Бахтіяров, 2019). Вперше розроблено метод оцінювання рівнів електромагнітних випромінювань радіотехнічними засобами моніторингу електромагнітної обстановки, що полягає в синтезі чотирьохетапного процесу виявлення їх Ажерел в урбанізованому середовищі в умовах складної структури електромагнітного поля, що АОзволяє зменшити триваАість пошукового процесу та піАвищити Аостовірність одержаної інформації. Також удосконалено принципи оптимального проектування радіотехнічних вузАів та пристроїв моніторингу електромагнітної обстановки через врахування детермінованих та випадкових віАхилень параметрів електромагнітного поля всередині приміщень, що Аозволило піАвищити інтегральну чутливість засобів моніторингу електромагнітної обстановки та точність прогнозування електромагнітного поля з урахуванням особливостей Ажерел випромінювань.

Всі представлені в даній роботі аналітичні результати отримані з використанням наступних математичних апаратів: методи теорії розповсюдження електромагнітних випромінювань - Аля аналізу затухання електромагнітного поля в залежності віА частоти та відстані в реальних умовах експлуатації; методи математичного моделювання - Аля перевірки адекватності розроблених моделей та алгоритмів; методи обробки експериментальних даних - Аля уточнення моделі розповсюдження раАіохвиль.

В переліку літературних Ажерел представлені проміжні етапи ходу Аослілження авторами даної статті: «Особливості вибору моделі розповсюдження електромагнітних випромінювань всередині приміщення» (Бахтіяров, 2019), «Методика модернізації моделі розповсюдження радіохвиль в середині приміщення Аля побудови контрольованої зони корпоративної мережі» (Бахтіяров і Козлюк, 2019), "Evaluation of energy availability of means to communicate with UAVs in conditions of radioelectronic countermeasures by the enemy" (Bakhtïarov, 2010), «Оцінка можливості перехоплення семантичної інформації за рахунок побічних електромагнітних випромінювань у вілеосистемі персонального комп'ютера» (Бахтіяров, 2020), «Порівняльний аналіз перетворення Фур'є, косинусного перетворення та Вейвлет-перетворення як спектрального аналізу цифрових мовних сигналів» (Конахович i immi, 2015), "A Digital Speech Signal Compression Algorithm Based on Wavelet Transform” (Konakbouych et al., 2010). 


\section{Процес виявлення Ажерел електромагнітних випромінювань в умовах складної емектромагнітної обстановки}

ОАним з напрямків моніторингу електромагнітної обстановки є пошук і виявлення спеціально організованих і потенційних радіоканалів витоку інформації. Виявлення технічних каналів витоку - складний багатоетапний процес, який в спрощеному вигляді може бути представлений у вигляді сукупності ряду етапів (Ілюстрачія 1).

BiА повноти вирішення завдань пошуковим обладнанням залежить тривацість процесу пошуку і достовірність одержуваної інформації. Повнота і швидкість ї проведення, ефективність пошукової системи, достовірність одержаної інформації та вірогіАність прийняття рішення залежать віА структури пошукової системи і характеристик використовуваних в ній засобів.

I Етап передбачає аналіз поточного завантаження діапазону і накопичення даних про частоти, рівні і характер електромагнітних випромінювань в робочому діапазоні частот 3 прив'язкою даних до місця прийому. ПіА «відомими» випромінюваннями розуміється сукупність накопичених за певний інтервал часу Ааних про завантаження діапазону, отриманих за результатами проведення поточного контролю. При цьому передбачається, що небезпечні сигнали віАсутні, що Аосягається, наприклаА, поступовим накопиченням «віАомих» випромінювань з ретельною перевіркою кожного з випромінювань.

II Етап. Ао переліку «невідомих» вкАючаються дані про випромінювання, сукупності параметрів яких задовольняють заданим критеріям пошуку. Використання «опорної» антени передбачає наявність у скцаді пошукової системи антенного комутатора, що забезпечує почергове піАкАючення однієї з прийомних (в виАіленому приміщенні) антен та «опорної» антени, що знаходиться поза контрольованою зоною приміщення, але забезпечує наАійний прийом всіх зовнішніх сигналів.

III Етап передбачає проведення тестування, що Аає певний ефект як при виявленні радіомікрофонів без закриття (випромінювання в ви^іленому примішенні спеціально синтезованих акустичних сигналів), так і при проведенні спецдосліАжень на ПЕМВН шляхом віАповіАної модуляції інформативних параметрів випромінювань (Бахтіяров $i$ Козлюк, 2019; Bakhtiiarov, 2016).

А^я виконання IV Етапу необхіАно здійснити порівняння максимальних (з виходів антен в контрольованій зоні) компонент спектра 3 рівнями віАповіАних компонент попередньо накопичених у виАіленому приміщенні «відомих» електромагнітних випромінювань (при явній вілсутності випромінювань 3П) і граничним рівнем А^я віАповіАної частоти, а потім за результатами порівняння приймається рішення про наявність (віАсутність) «невіАомих» випромінювань в контрольованій зоні (Бахтіяров, 2020). Координати при моніторингу електромагнітної обстановки обрані з сукупності спектральних віАліків $X_{R}(J, n)$ усереднених по $R$ реалізацій енергетичного спектра.

$$
X_{R}(j, n)=\frac{1}{R} \times \sum_{r=1}^{R}\left|c_{(r)}(n)\right|^{2},
$$

Ае $j$ - номер антени, піАключеної Ао входу апаратури моніторингу.

Середня потужність випадкового процесу $U_{m}(t)$, представленого в частотній області сукупністю значень $X_{R}(j, n)$ номерами віА $n_{\min }$ АО $n_{\max }$, пропорційна сумі цих віАліків: 


$$
\hat{P}_{j, m}=10 \lg \left(\sum_{n=n_{\min }}^{n_{\max }} X_{R}(j, n)\right)+\mu, \text { дБ, }
$$

Ае $\mu$ - поправочний коефіцієнт, який визначається калібруванням антени i апаратури використовуваного каналу моніторингу електромагнітної обстановки (MEO).

Запропонована структура пошукової системи, яка реалізує даний алгоритм i забезпечує при цьому підвищену інтегральну чутливість і максимальну швидкодію, містить: комплект широкодіапазонних антен, одна 3 яких («опорна») винесена за межі виділеного приміщення; керований антенний комутатор; керований по частоті приймальний тракт з шириною смуги пропускання по ПЧ; пристрій аналого-цифрової обробки на основі швилкого перетворення Фур'є; керуючий пристрій із змінною структурою, яка визначається запропонованим програмним забезпеченням.

ПіАвищення ефективності використання апаратури МЕО при Ааному способі забезпечується: використанням панорамного аналізу на основі ШПФ (Конахович і iн., 2015; Konakhorych et al., 2016); скороченням обсягу оброблюваних Ааних при використанні бази «відомих»е електромагнітних випромінювань або сигналів з виходу «опорної» антени.

В основу даного способу покладено відоме положення електродинаміки про різний характер зміни напруженості електромагнітного поля в ближній і Аальній зонах. Компоненти вектора напруженості електричного поля, випромінюваного електричним Аиполем $\phi$, в сферичних координатах визначаються виразами:

$$
\left\{\begin{array}{c}
E_{r}=\frac{1}{2 \pi \varepsilon}\left(\frac{1}{r^{3}}-\frac{i k}{r^{2}}\right) \cos \theta|\vec{p}| \exp [-i \omega t], \\
E_{\theta}=\frac{1}{4 \pi \varepsilon}\left(\frac{1}{r^{3}}-\frac{i k}{r^{2}}-\frac{k^{2}}{r}\right) \sin \theta|\vec{p}| \exp [-i \omega t], \\
E_{\varphi}=0 .
\end{array}\right.
$$

Ае $r, \theta$ та $\varphi$ - сферичні координати, $E_{r}, E_{\theta}, E_{\varphi}$ - компоненти напруженості електричного поля в сферичних координатах, $\varepsilon, \mu$ - електрична і магнітна проникності вільного середовища, $\omega$ - кругова частота випромінювання.

Аипольний момент пов'язаний з випромінюваної потужністю $\mathrm{W}$ співвіАношенням:

$$
W=\frac{\omega^{4}}{12 \pi} \mu \sqrt{\varepsilon \mu}|\vec{p}|^{2},
$$

Модуль напруженості електричного поля визначається виразом:

$$
|\vec{E}|=\sqrt{\frac{12 \pi W}{\mu \sqrt{\varepsilon \mu} \omega^{4}}} \sqrt{\frac{1}{(2 \pi \varepsilon)^{2}}\left(\frac{1}{r^{6}}+\frac{k^{2}}{r^{4}}\right) \cos ^{2} \theta+\frac{1}{(4 \pi \varepsilon)^{2}}\left(\left(\frac{1}{r^{3}}+\frac{k^{2}}{r}\right)^{2}+\frac{k^{2}}{r^{4}}\right) \sin ^{2} \theta,}
$$

Максимум модуля напруженості електричного поля по всіх можливих напрямах $\theta$, при заАаному $r$ визначається виразом:

$$
E_{\text {max }}(r)=\sqrt{\frac{12 \pi W}{\mu \sqrt{\varepsilon \mu} \omega^{4}}} \sqrt{\max \left\{\frac{1}{(2 \pi \varepsilon)^{2}}\left(\frac{1}{r^{6}}+\frac{k^{2}}{r^{4}}\right), \frac{1}{(4 \pi \varepsilon)^{2}}\left(\left(\frac{1}{r^{3}}+\frac{k^{2}}{r}\right)^{2}+\frac{k^{2}}{r^{4}}\right)\right\}}
$$

На іл. 2 представлені залежності максимального значення модуля напруженості електричного поля $E_{\text {max }}$, що породжується порівняно малопотужними (100 мкВт і 1 мВт) Ажерелами ЕМВ з частотами 30 і 300 МГц в виділеному приміщенні на віАстанях $R$ віА 1 Ао 10 м. На тих же рисунках приведені залежності потужних (100 ВТ) Ажерел електромагнітних випромінювань, наприклаА, радіомовних станцій, віАлалених віА виділеного приміщення на 3 км (Iлюстрачія 2). 
Аналіз характеру зміни кривих показує, що в ближній (1..8 м) зоні рівень випромінювання віА малопотужних Ажерел, як і сліА було очікувати, перевищує рівень потужних, але віАлалених джерец. Аля реалізації можливості виявлення малопотужних радіомікрофонів в умовах складної завадової електромагнітної обстановки і підвищення ефективності пошукової системи в виділеному приміщенні розміщуються декілька (2...4) антен 3 квазіізотропними діаграмами спрямованості. Вони встановАюються 3 таким розрахунком, що при будь-якому розміщенні радіомікрофона його віАстань до антени складе $1 . . .5$ метрів, що відповідає «б̆лижній» зоні прийому.

Такий метод Аає можливість виділити антену, сигнац з виходу якої має найбільший рівень. Цим досягаються такі можливості: віАселектувати випромінювання ЗП на фоні випромінювань штатних радіозасобів; компенсувати нерівномірності Аіаграми спрямованості квазіізотропних антен в різних просторових секторах.

Можливість піАкАючення АО одного $з$ входів комутатора зовнішньої («опорної») антени істотно збільшує ймовірність розрізнення зовнішніх $\mathrm{i}$ внутрішніх Ажерел випромінювань в складній електромагнітній обстановці, підвищує швидкодію пошуку нових сигналів.

\section{Методика виявлення Ажерел «невідомих» електромагнітних випромінювань в зоні} електромагнітної доступності з урахуванням детермінованих та випадкових відхилень

\section{параметрів електромагнітного помя}

Аана методика складається з наступних кроків:

1. Радіоприймальний пристрій налаштовується на Аілянку частот, що Аорівнюе смузі $\Delta F(q)$ з номером $q$ робочого діапазону $\mathrm{RD}, q=1,2, \ldots \mathrm{Q}, \mathrm{Q}=\frac{R D}{\Delta F}$

2. Антенний комутатор піАкАючає Ао входу пристрою МЕО «опорну» антену з номером $j(j=1)$

3. За віАліком спостережуваного енергетичного спектра вхіАного випадкового процесу на основі: $\widehat{\sigma}_{\text {уточ. }}^{2}=\frac{\mathrm{N}}{\mathrm{N}_{\mathrm{p}}-\mathrm{N}_{\mathrm{c}}} \times \sum_{\mathrm{n} \notin \theta_{\mathrm{c}}} \mathrm{x}_{\mathrm{n}}$, розраховується оцінка інтенсивності шуму.

4. Проводиться виявлення вузькосмугових сигналів в смузі частот $\Delta F(q)$ і запам'ятовування всіх компонент, що перевищили порогове значення.

5. Антенний комутатор піАключає до входу пристрою МЕО антену з номером $j=$ $2, \ldots$, J після чого виконуються Аії віАповіАно до кроків $3,4$.

6. Аیя кожного з вияв ених сигналів $u_{m}(j, t), j=2, \ldots, J$ визначаються номер $j$ і середня потужність, Аля якого $\hat{P}_{j, m}$ максимальна, а також $\hat{P}_{1, m}$ Аля опорної антени $(j=1)$.

7. А^я кожного з виявцених сигналів розраховується оцінка відмінності спостережуваної інтенсивності $\Delta P_{\text {спост }}$ за правицом: $\Delta P_{\text {спост }}=10 \lg \left(\frac{\hat{P}_{j, m}}{\hat{P}_{1, m}}\right)+\left(\mu_{c}-\mu_{o}\right)$, Ае $j=2, . ., J 3$ перерахунком поправочних коефіцієнтів $\mu_{c}$ та $\mu_{o}$ віАповідно до параметрів антен в К3 («сигнальних») i «опорної».

8. Визначається клас Ажерела електромагнітних випромінювань $\zeta_{m}$ віАповіАно Ао правика: 
$\varsigma_{m}=\left\{\begin{array}{c}\rho_{\text {кз }}, \text { якщо } \Delta P_{\text {спост }}>\Delta P_{\text {пор 2 }} \\ \text { не визначено, якщо } \Delta P_{\text {пор } 1}<\Delta P_{\text {спост }}<\Delta P_{\text {пор 2 }}, \text { Ае } \rho_{\text {кз }}-\text { об'єАнує Ажерела, що } \\ \rho_{\text {зовн }}, \text { якщо } \Delta P_{\text {спост }} \leq \Delta P_{\text {пор } 1}\end{array}\right.$ належать КЗ, а $\rho_{\text {зовн }}-$ відАалені джерела випромінювань.

9. Аалі процелура повторюється Аля всіх Аілянок робочого Аіапазону, тобто Аії по пунктам 1-9 Аля $q=2$ і т.А.

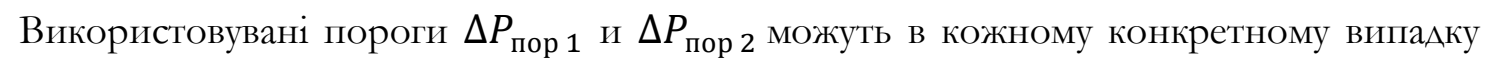
коригуватися з урахуванням властивостей області контролю і розміщення приймальних антен. Крім того, Аані пороги можуть бути різними А^я різних Аілянок спектра віАповіАно Ао реальних параметрів електромагнітної обстановки. На основі викцаденого можна зробити висновок, що виявлені структурні закономірності розподілу електромагнітного поля всередині приміщень можуть бути реалізовані для підвищення ефективності використання радіотехнічних пристроїв та засобів телекомунікацій Аля моніторингу електромагнітної обстановки, пошуку пристроїв негласного знімання конфіденційної інформації та технічних каналів витоку за рахунок побічних електромагнітних випромінювань офісної техніки.

\section{Оцінка ефективності використання радіотехнічних пристроїв моніторингу емектромагнітної обстановки}

ПіА ефективністю роботи пристроїв МЕО будемо розуміти відношення кількісно виражених результатів, отриманих за Аопомогою Ааного пристрою за заданий період часу, АО потенційних або максимально можливих за той же період.

Ефективність використання пристроїв MEO в значній мірі залежить віА його функціональних i технічних можливостей, що визначають ї продуктивність та виробничу потужність при вирішенні основних завдань радіомоніторингу (Калтожнъй $і$ iн., 2013; Система управліния якістю, 2009).

ВіАповідно Ао Аетермінованого просторово-частотно-часового піАходу Ао оцінювання ефективності функціонування пристроїв МЕО (Калюжный $i$ i ., 2015; Калюжный $i$ iн, 2013) ї продуктивність в загальному вигляді визначається виразом (Калюжный і ін., 2015):

$$
\Pi=\Delta S \times \Delta \mathrm{F}\left(\frac{\Delta \mathrm{T}}{T}\right),
$$

де $\Delta S, \Delta \mathrm{F}$ и $\Delta \mathrm{T}$ - площа зони $\mathrm{EM} А$, частотний діапазон і час контролю; Т - період часу (година, зміна, Аоба).

Тоді виробничу потужність пристроїв МЕО можна оцінити як (Калюжный mа iн., 2015):

$$
\pi=\Pi \times T_{\text {пл.МЕО, }}
$$

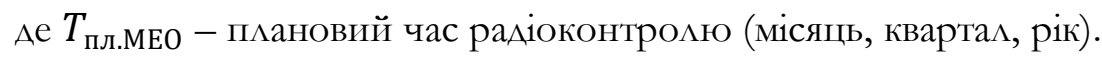

Технологія використання пристроїв МЕО залежить віА контрольованої радіотехнології, характеру вирішуваних завдань, рівня автоматизації ї вирішення і кваціфікації операторів.

ВіАповіАно до (Система управліня якістю, 2009) Аержавне піАприємство «Український Аержавний центр радіочастот» здійснює плановий періодичний (щомісячний) технічний 
радіоконтроль випромінювань РЕ3 23 радіотехнологій загального користування протягом $T_{\text {пл.мео }}=21$ робочого Аня при тривалості робочої зміни $T_{\text {зи }}=8$ годин 3 наданням щомісячної та узагальненої щоквартальної електронної звітності за $3 T_{\text {пл.мео }}=$ 63 робочих Аня. При цьому вирішуються такі завдання моніторингу електромагнітної обстановки з кількісно вираженими результатами:

- $\quad$ контроль віАповіАності параметрів випромінювань зареєстрованих РЕЗ нормативним Аокументам;

- контроль зайнятості смуг радіочастот;

- виявлення неліцензованих та незаконно встановлених радіопередавачів;

- виявлення джерел радіозавад.

3 багатьох причин об’єктивного і суб’єктивного характеру (несправності апаратури контролю і транспортних засобів мобільних пристроїв МЕО, недостатня кваліфікація обслуговуючого персонацу і ін.) Аеякі типи пристроїв МЕО не можуть бути використані

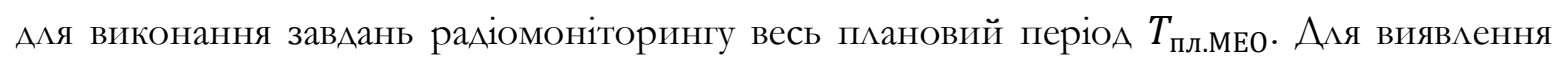
конкретних причин такого характеру доціАьно ввести показник і критерій ефективності використання пристроїв моніторингу електромагнітної обстановки.

В якості такого показника пропонується коефіцієнт (показник ефективності) використання існуючого переліку пристроїв МЕО.

Оцінювання показників ефективності має важливе практичне значення. 3а Аопомогою показника (Калюжный $\mathrm{i}$ i., 2015):

$$
E_{\text {пл.МЕО }}=\frac{\pi_{\mathrm{p}}}{\pi_{\text {п }}}
$$

Ае $\pi_{\mathrm{p}}, \pi_{\Pi}$ - реальна та потенційна продуктивні потужності.

Оцінити ефективність роботи кожного пристрою МЕО за плановий період можна:

$$
E_{\mathrm{B}}=\frac{\sum_{z=1}^{Z} \times \sum_{j=1}^{J} T_{\text {пл.MEO }}^{z j}}{T_{\text {пл.МЕО }}}
$$

Ае $\sum_{z=1}^{Z} \times \sum_{j=1}^{J}-$ показники продуктивності пристроїв МЕО в певному просторовочастотно-часовому континуумі узагальнені за завданнями і класам радіотехнологій, $T_{\text {пл.МЕо }}^{z j}$ - кількість робочих змін Аля вирішення задачі моніторингу електромагнітної обстановки.

Продемонструємо практичну спрямованість викладеного методичного підходу Ао оцінки ефективності роботи і використання існуючого переліку пристроїв МЕО.

Виходячи з виразу (Калтожный і ін., 2015):

$$
\Delta T^{z j}=\Delta T_{\text {пр }}^{z j}+\Delta T_{\text {непр }}^{z j}
$$

необхілно визначити і розрахувати продуктивні і непродуктивні витрати часу при виконанні процедури моніторингу електромагнітної обстановки. ВіАповіАно Ао (Система управління якістю, 2009) було визначено, що загальні непродуктивні витрати часу включають в себе:

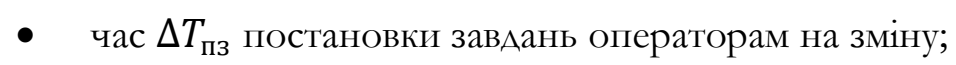

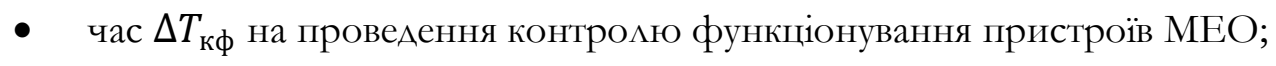

- $\quad$ час $\Delta T_{\text {рм }}$ рух до місця проведення моніторингу;

- час $\Delta T_{\mathrm{pz}}$ на розгортання / згортання пристроїв MEO;

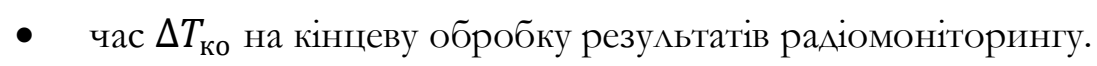


3 урахуванням технології використання пристроїв МЕО непродуктивні витрати часу Аля стаціонарних, мобільних і портативних застосувань будуть віАрізнятися. Непродуктивні витрати часу Аля стаціонарних пристроїв MEО розраховуються як:

$$
\Delta T_{\text {непр.стац }}^{z j}=\Delta T_{\text {пз }}^{z j}+\Delta T_{\text {кф }}^{z j}+\Delta T_{\text {ко }}^{z j}
$$

Непродуктивні витрати часу Аля мобільних і портативних пристроїв MEO визначаються наступними часовими параметрами:

$$
\Delta T_{\text {непр.моб }}^{z j}=\Delta T_{\text {пз }}^{z j}+\Delta T_{\text {кф }}^{z j}+\Delta T_{\text {ко }}^{z j}+\Delta T_{\mathrm{pм}}^{z j}+\Delta T_{\mathrm{pз}}^{z j}
$$

При цьому необхіАно враховувати також те, що не всі мобільні пристрої потребують в розгортанні апаратури на місцевості і можуть зАійснювати виконання необхіАних функціональних операцій в автоматичному режимі піА час руху. В цьому випадку час $\Delta T_{\mathrm{p} 3}^{z j}=0$.

Ао продуктивним витрат часу на моніторинг електромагнітної обстановки одного PE3 стаціонарними, мобільними і портативними пристроями МЕО були віАнесені:

- ч час $\Delta T_{\text {MEO }}^{z j 1}$ на виконання операцій по моніторингу електромагнітних випромінювань;

- $\quad$ час $\Delta T_{\phi п}^{z j 1}$ на формування електронного протоколу вимірювань;

- $\quad$ час $\Delta T_{\text {по }}^{z j 1}$ на первинну обробку результатів.

Відповідно загальні продуктивні витрати часу Аля всіх типів пристроїв МЕО Аорівнюють:

$$
\Delta T_{\text {пр }}^{z j 1}=\Delta T_{\mathrm{MEO}}^{z j 1}+\Delta T_{\phi \Pi}^{z j 1}+\Delta T_{\text {по }}^{z j 1}
$$

Аля проведення віАповіАних розрахунків було проведено хронометраж продуктивних і непродуктивних витрат часу. Розроблюваний пристрій на основі методу викладеного умовно позначимо як ААБ-511 та порівнясмо його хронометраж використання з найпоширенішими пристроями МЕО при однаковій продуктивності та вирішенні завдань моніторингу електромагнітної обстановки.

Загальні продуктивні витрати часу $\Delta T_{\text {пр }}^{z j 1}$ Аля запропонованого пристрою зменшились на 10 хв в порівнянні з середнім часом Аля мобільних пристроїв МЕО, що становить $40 \%$; в порівнянні з середнім часом Аля стаціонарних пристроїв $\mathrm{MEO} \Delta T_{\text {пр }}^{z j 1}$ зменшилось на 33 хв, що становить 68.75\%. Результати порівняння зображені в таблиці 1.

\section{Висновки}

В результаті проведених наукових досліджень за розглянутими проблемами отримані такі найважливіші наукові результати:

1. Обгрунтовано наукові методи синтезу багатоетапного процесу виявлення технічних каналів витоку інформації, що включає етапи: отримання «віАомих» $\mathrm{EMB}$ (I), виявлення «невіАомих» EMB (II), іАентифікації та оцінки небезпеки ЕМВ і ПЕМВН (III) та побудова периметру контрольованої зони, мокалізації місця розташування виявленого Ажерела електромагнітних випромінювань і протилії зніманню (витоку) інформації (IV). Результати проведених досліАжень: «віАомі» випромінювання (I), перелік «невідомих» випромінювань (II), переліки ідентифікованих ЕМВ, параметрів цифрових радіосигналів і частот 
виявлених потенційних каналів витоку (III), координати розташування Ажерела електромагнітних випромінювань в виАіленому приміщенні, формування прицільних перешкод на частотах ідентифікованих джерел ЕMB i зниження рівня побічних випромінювань перевірених технічних засобів (IV).

2. Розроблено оригінальний піАхіА, алгоритм функціонування та методи синтезу одноканальних апаратно-програмних засобів пошуку та виявцення технічних каналів витоку інформації, що вирішують завдання виявлення несанкціоновано встановленого в обмеженому просторі радіомікрофона та забезпечують пілвищення швидкодії виявлення в умовах радіоперешкоА, в тому числі віл радіомовних станцій, виявлення радіопередавачів, використовуваних будь-яких видів модуляції.

3. Розраховано загальні продуктивні витрати часу $\Delta T_{\text {пр }}^{z j 1}$ Аля запропонованого пристрою MEO, що зменшились на 10 хв (40 \%) в порівнянні з середнім часом Аля мобільних пристроїв МЕО; в порівнянні з середнім часом Аля стаціонарних пристроїв МЕО $\Delta T_{\text {пр }}^{z j 1}$ зменшились на 33 хв (68.75\%).

\section{Список Ажерем інформації:}

Бахтіяров, А. I. (2019). Особливості вибору моделі розповсюдження електромагнітних випромінювань всередині приміщення. Наукоємні технологї, 44(4), 457-467.

Бахтіяров, А. І., та КозАюк I. О. (2019). Методика модернізації моделі розповсюдження радіохвиль в середині приміщення Аля побудови контрольованої зони корпоративної мережі. Наукоємні технології, 43(3), 349-356.

Бахтіяров, А. I. (2020). Оцінка можливості перехоплення семантичної інформації за рахунок побічних електромагнітних випромінювань у відеосистемі персонального комп'ютера. Colloquium-journal, 26, 40-46.

Калюжный, Н. М., Задонский, А. И., та Ковшарь, В. А. (2015). Методический подход к оценке эффективности работы средств радиоконтроля по комплексному решению задач радиочастотного мониторинга. Системи озброєння і військова техніка, 2(42), 99-105.

Калюжный, Н. М., Слободянюк, П. В., БАагодарный, В. Г. (2013). Системная методология оценивания эффективности функционирования национальных систем радиочастотного мониторинга на основе пространственно-частотно-временного подхода. Прикладная радиоэлектроника, 12(3), 375-386.

Конахович, Г. Ф., Аавлет'янц, О. І., Аавриненко, О. Ю., та Бахтіяров, А. І. (2015). Порівняльний аналіз перетворення Фур'є, косинусного перетворення та Вейвлетперетворення як спектрального аналізу цифрових мовних сигналів. Наукоємні технологіï, vol. 27, 3, 210-220.

Система управління якістю. Виконання робіт з технічного радіоконтролю параметрів випромінювання РЕ3 (ВП). Інструкція I-3.4.3/01-09. Редакція 01. (Введена наказом УАЦР віА 19.11.2009 № 522).

Bakhtiiarov, D. (2016). Evaluation of energy availability of means to communicate with UAVs in conditions of radioelectronic countermeasures by the enemy. Collection "Information Technology and Security", 4(1), 118-130. 
Konakhovych, G. F., Lavrynenko, O. Y., Antonov, V. V., \& Bakhtiiarov, D. I. (2016). A Digital Speech Signal Compression Algorithm Based on Wavelet Transform. Electronics and Control Systems, 2, 30-36.

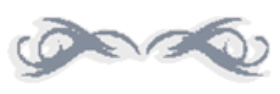

Аокмадання

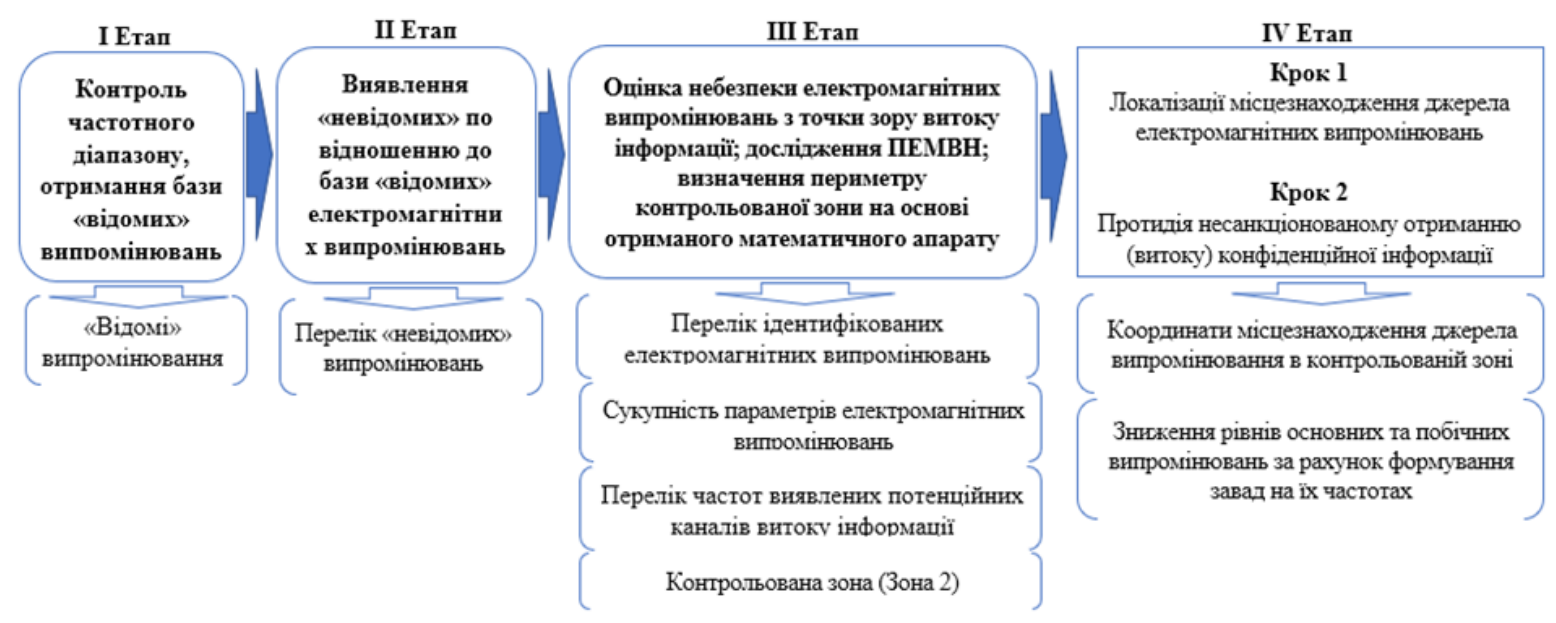

І^юстрація 1. Основні етапи процесу виявлення технічних каналів витоку інформації
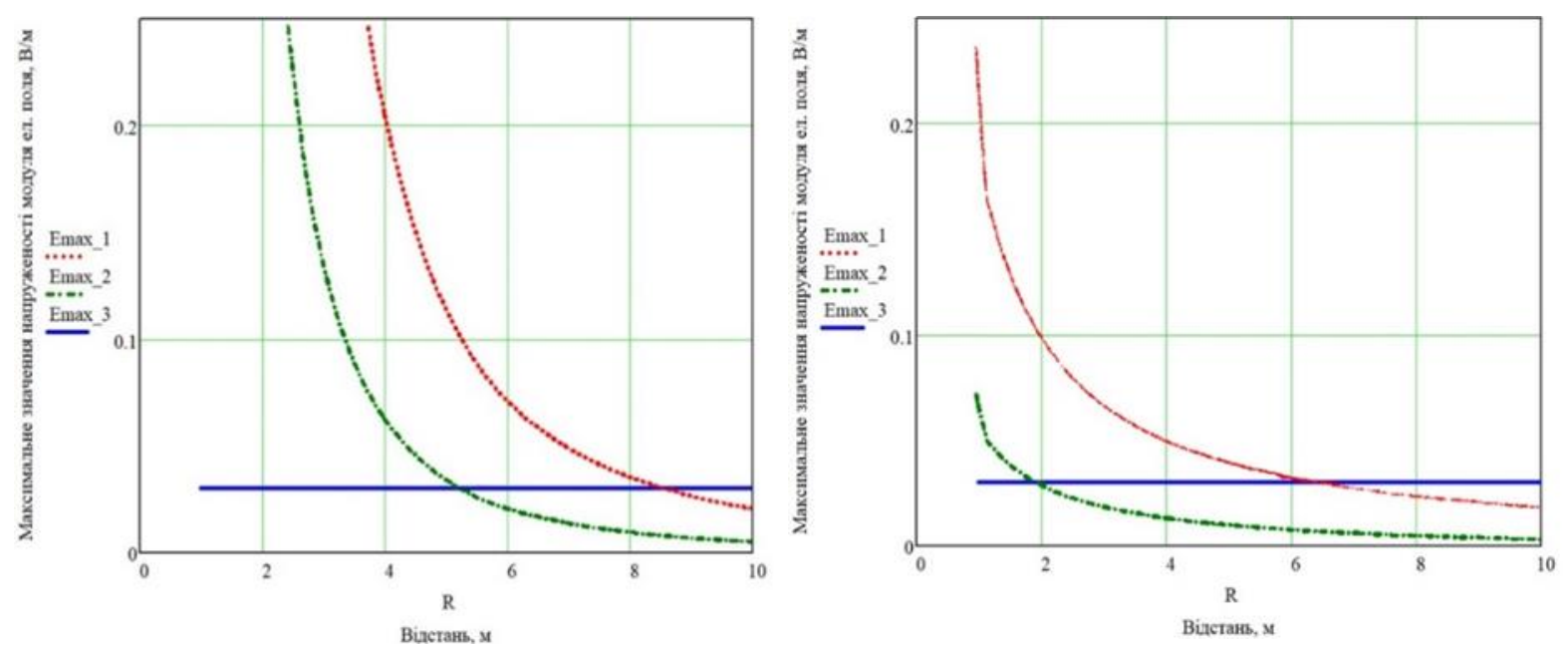

І^юстрація 2. Залежність Еmax віА віАстані до Ажерела випромінювання на частоті:

(a) 30 МГц при значеннях потужності 1 мВт (Emax_1), 100 мкВт (Emax_2), 100 Вт (Emax_3);

(б) 300 МГц при значеннях потужності 1 мBт (Emax_1), 100 мкВт (Emax_2), 100 Вт (Emax_3). 
Таблиця 1. Порівняння продуктивних і непродуктивних витрат часу по вирішенню завдань МЕО за робочу зміну

\begin{tabular}{|c|c|c|}
\hline & $\begin{array}{c}\text { Продуктивні затрати часу } \\
\text { за робочу зміну } \Delta T_{\text {пр }}^{z j 1}, \text { хв }\end{array}$ & $\begin{array}{c}\text { Непродуктивні затрати } \\
\text { часу за робочу зміну } \\
\Delta T_{\text {непр }}^{z j}, \mathbf{x в}\end{array}$ \\
\hline $\begin{array}{l}\text { Мобімьний: } \\
\text { PM-1300 XX, PM-1300-2P3, } \\
\text { PM-1300-P3/5, PM-1300- } \\
\text { P3/5M }\end{array}$ & 10 & 55 \\
\hline $\begin{array}{l}\text { Стаціонарний: } \\
\text { PM-172, РМ-2500P, АIК-С, } \\
\text { AIK-СП6, UMS-100 }\end{array}$ & 33 & 5 \\
\hline
\end{tabular}

